\title{
The transition from the transfemoral to transradial approach in the high-volume percutaneous coronary intervention center
}

\author{
Hrvoje Pintarić* \\ University Hospital Center "Sestre milosrdnice", Zagreb, Croatia
}

Although the first percutaneous transradial approach (TRA) for diagnostic coronary angiography was described in 1989 and first interventional use in 1993, its practice has been largely disregarded by operators traditionally trained in the femoral approach (FA). The TRA increases patient comfort and reduces vascular complications and major bleeding ${ }^{1,2}$.

At the ACC.11 \& i2 Summit 2011 Bertrand et al presented a meta-analysis of 73 studies (14 randomized, 59 observational) involving a total of $1,022,123$ patients. There was a strong association between TRA and mortality early after intervention (OR 0.52, 95\% credible interval [Crl] 0.43-0.62), although the beneficial effect compared to FA was mainly due to the observational studies. An association between TRA and death or MI was observed over short-term followup (OR $0.66,95 \% \mathrm{Crl} 0.51-0.82)$, with an OR of 0.72 (95\% Crl 0.41-1.14) for long-term follow-up. Compared with FA, TRA was associated with a major reduction in bleeding (OR $0.22,95 \% \mathrm{Crl} 0.16-0.29$ ) and in transfusions (OR 0.20, 95\% Crl 0.10-0.31) ${ }^{3}$.

A learning curve exists for the radial approach that will affect procedure time and radiation dose, with a trend toward lower procedural success rates for radial versus femoral access. Dispite the fact that TRA requires a longer learning curve than FA, the transradial challenges are usually overcome with experience. Nowadays, in view of its benefits, there is no longer any justification for ignoring the transradial approach ${ }^{4}$. Multiple randomized clinical trials and reports consistently demonstrate benefits to the patient and improved outcomes from TRA ${ }^{5}$. TRA is particularly appealing in patients with coagulopathy, elevated international normalized ratio due to warfarin, or morbid obesity ${ }^{6}$.

Radial artery occlusion (RAO) is an infrequent (3\% to $10 \%$ ) and clinically silent complication of TR catheterisation (in properly selected cases) while other complications are less common $^{7-10}$. Unfortunately RAO occurrence precludes any future TRA. There is evidence that up to half of RAO are recanalised at 30-day follow up. Heparin has been shown to significantly reduce the incidence of RAO and a clear relationship exists between the heparin dose and the rate of RAO.
Institutions that perform more than 400 elective PCls per year and more than 36 primary $\mathrm{PCI}$ procedures for STEMI per year are considered to be a high-volume centers. Older observational evidence supported a volume-outcome relationship in $\mathrm{PCl}$ at both the institutional and operator level. However, more recent data on primary $\mathrm{PCl}$ suggest that operator experience may modify the volume-outcome relationship at the institutional level ${ }^{11}$.

TRA-PCI can be performed by low-to-intermediate volume operators with standard equipment with a low failure rate. Age over 75 years, prior coronary artery bypass graft surgery, and short stature are independent predictors of TR$\mathrm{PCl}$ failure ${ }^{12}$. Appropriate patient selection and careful risk assessment are needed to maximize benefits offered by TR$\mathrm{PCl}$. Specific technical challenges related to TRA are most often overcome with experience. Understanding the problem will prevent complications and allow successful management.

Bertrand and his group analyzed responses from 1,107 interventional cardiologists in 75 countries. Overall, approximately $50 \%$ responded that their TRA practice will increase in the future $(68.4 \% \text { in the United States })^{3}$.

KEYWORDS: transradial approach, coronary angiography, percutaneous coronary intervention; learning curve.

\section{Received: $8^{\text {th }}$ Mar 2013}

*Address for correspondence: Klinički bolnički centar "Sestre milosrdnice", Vinogradska cesta 29, HR-10000 Zagreb, Croatia.

Phone: +385-1-3787-965

E-mail: hrvojepintaric@yahoo.com

\section{Literature}

1. Jolly SS, Amlani S, Hamon M, Yusuf S, Mehta SR. Radial versus femoral access for coronary angiography or intervention and the impact on major bleeding and ischemic events: a systematic review and meta-analysis of randomized trials. Am Heart J. 2009;157:132-40.

2. Barbeau GR, Arsenault F, Dugas L, Simard S, Lariviere MM. Evaluation of the ulnopalmar arterial arches with pulse oximetry and plethysmography: comparison with the Allen's test in 1010 patients. Am Heart J. 2004;147:489-93.

3. Bertrand OF, Rao SV, Pancholy S, et al. Transradial approach for coronary angiography and interventions: results of the First International Transradial Practice Survey. J Am Coll Cardiol Intv. 2010;3(10):1022-1031. 
4. Rao SV, Ou FS, Wang TY, et al. Trends in the prevalence and outcomes of radial and femoral approaches to percutaneous coronary intervention: A report from the national cardiovascular data registry. J Am Coll Cardiol Intv. 2008;1:379-86.

5. Rao SV, Cohen MG, Kandzari DE, et al. The transradial approach to percutaneous coronary intervention: historical perspective, current concepts, and future directions. J Am Coll Cardiol. 2010;55:2187-95

6. Chese AJ, Fretz EB, Warburton WP, et al. Association of the arterial access site at angioplasty with transfusion and mortality: the M.O.R.T.A.L. study (Mortality benefit of Reduced Transfusion after percutaneous coronary intervention via the Arm or Leg). Heart. 2008;94:1019-25

7. Spaulding C, Lefevre T, Funck F, et al. Left radial approach for coronary angiography: results of a prospective study. Cathet Cardiovasc Diag. 1996;39:365-70.

8. Stella PR, Kiemeneij F, Laarman GJ, et al. Incidence and outcome of radial artery occlusion following transradial artery coronary angioplasty. Catheter Cardiovasc Diagn. 1997;40:156-8.

9. Romagnoli E, Nasso G, Angeloni G, et al. Cardiovocal Syndrome after transradial catheterization: An unusual complication. Int J of Cardiol. 2008;124:39-41.

10. Park KW, Chung JW, Chang SA, II Kim K, Chung WY, Chae IH. Two cases of mediastinal hematoma after cardiac catheterization: a rare but real complication of the transradial approach. Int J of Cardiol. 2008;130:99-92.

11. Levine GN, Bates ER, Blankenship JC, et al. 2011 ACCF/AHA/SCAI Guideline for Percutaneous Coronary Intervention. A report of the American College of Cardiology Foundation/American Heart Association Task Force on Practice Guidelines and the Society for Cardiovascular Angiography and Interventions. J Am Coll Cardiol. 2011;58:e44-122. 12. Dehgani P, Mohammad A, Bajaj R, et al. Mechanism and predictors of failed transradial approach for percutaneous coronary interventions. J Am Coll Cardiol Interv. 2009;2:105764.

\title{
Prošireni sažetak / Extended abstract
}

\section{Bifurcation stenosis on diagnostic coronary angiography after resuscitation of patients with ischemic cardiomyopathy - a case report}

\author{
Đeiti Prvulović*, Irzal Hadžlbegović, Božo Vujeva, Krešimir Gabaldo \\ General Hospital "Dr J. Benčevic", Slavonski Brod, Croatia
}

Case report: 55 year old male, 2 years earlier anteroseptal STEMI, stenting of pLAD, ischemic cardiopathy with EF $40 \%$. Cardiac arrest with ventricular fibrillation, without ACS, the true bifurcation stenosis of strong CxA-OM1, Medina $1,1,1$.

\section{Received: $5^{\text {th }}$ Mar 2013}

*Address for correspondence: Andrije Štampara 42, HR-35000 Slavonski Brod, Croatia.

Phone: +385-35-201-201

E-mail: deiti. prvulovic@sb.t-com.hr
Questions for discussion: type of revascularization (PCI vs. CABG), implantation of ICD or not, the order and the timing of these procedures. Authors show how the patient was treated in our institution with reference to current guidelines.

KEYWORDS: coronary artery disease, percutaneous coronary intervention, revascularosation. 